\title{
Posttraumatic growth measures: translation and adaptation of three self-report instruments to Brazilian Portuguese
}

\author{
Thiago Loreto Garcia da Silva ${ }^{1}$, Júlia Candia Donat¹, Gustavo Gauer², Christian Haag Kristensen ${ }^{1}$ \\ ${ }^{1}$ Centre of Studies and Research in Traumatic Stress, Post-Graduate Program in Psychology, Pontifícia Universidade Católica do Rio Grande do Sul (PUC-RS), Porto Alegre, RS, Brazil \\ 2 Federal University of Rio Grande do Sul (UFRGS), Post-Graduate Program in Psychology, Porto Alegre, RS, Brazil
}

Received: 4/24/2016 - Accepted: 6/30/2016

DOI: 10.1590/0101-60830000000083

\begin{abstract}
Background: Posttraumatic growth is one of the most commonly used concepts to evaluate positive changes after trauma. The principal scales used internationally to evaluate this phenomenon have not yet a Brazilian Portuguese version. Objectives: This study aimed to translate and adapt to the Brazilian context the Posttraumatic Growth Inventory (PTGI), the Core Beliefs Inventory (CBI), and the Event Related Rumination Inventory (ERRI). Methods: The procedures included translation, back translation, expert committee's evaluation, and pilot testing in the target population. Results: All items of all three instruments had a good content validity index after evaluation by four experts and three reformulations. The back translation of the final version also demonstrated that all Brazilian Portuguese versions convey the same meaning as the original English version. The final version was pilot tested with 30 undergraduate students, and all the items were above the cut-off point. Discussion: This study was able to produce Brazilian versions of the PTGI, CBI, and ERRI. Further studies are underway to determine the reliability, factorial validity, and convergent validity of the subscales of the instruments.
\end{abstract}

Silva TLG et al. Arch Clin Psychiatry. 2016;43(3):47-50

Keywords: Transcultural adaptation, posttraumatic growth, trauma, PTSD, psychometrics.

\section{Introduction}

Although it is estimated that 40 to $90 \%$ of people will be exposed to at least one traumatic event in the course of life, only $10 \%$ of those will develop psychiatric disorders, such as posttraumatic stress disorder (PTSD) ${ }^{1,2}$. These figures suggest that negative outcomes are not the only type of experience in the aftermath of trauma. Several studies have shown that an individual's struggle with a traumatic event can produce negative, positive, and, perhaps even more typically, a mixture of negative and positive experiences ${ }^{3,4}$.

Posttraumatic growth (PTG) is one of the most commonly used concepts to evaluate the positive outcomes of trauma. PTG is defined as a positive change experienced as a result of the struggle with a major life crisis or traumatic event, a change beyond mere adjustment and recovery ${ }^{5,6}$. The underlying idea is that it is not the event itself that defines the outcome, but how this experience challenges people's beliefs about the world and self3,4. PTG can be achieved as a consequence of the process of attempting to understand the event (e.g., deliberate rumination) and the cognitive effort to redefine those beliefs and the assumptive world 7,8 .

Previous studies have shown an association of PTG with greater life satisfaction, well-being and quality of life in the long term after not only traumatic events but also extremely adverse situations, such as cancer ${ }^{9}$ and coronary heart disease ${ }^{10}$. Even though PTG has received empirical support, the theoretical model should be further developed many hypotheses have yet to be tested ${ }^{3}$.

A widely used inventory for investigating PTG is the Posttraumatic Growth Inventory (PTGI) ${ }^{5}$, which consists of 21 self-report items scored on a six-point Likert scale. A total score can be used, but the scale also has a five-factor model that reflects different domains of growth: Relating to others (RO); Personal strength (PS); New possibilities (NP); Appreciation of life (AL); and Spiritual change (SP) ${ }^{5,11}$. The internal consistency for the total score and subscales of the PTGI has been reported as satisfactory ( $\alpha$ coefficient for the total score $=.90, \mathrm{RO}=.85, \mathrm{NP}=.84, \mathrm{PS}=.72, \mathrm{SP}=.85$, and $\mathrm{AL}=.67$ ), just as the test-retest reliability $(\mathrm{r}=.71)^{5}$. The PTGI has already been translated and adapted to different languages, such as Chinese ${ }^{12}$, Spanish $^{13}$, Dutch ${ }^{14}$, Japanese ${ }^{15}$, and European Portuguese ${ }^{16}$.

For a broader understanding of PTG, it is necessary to consider not only the subjectively perceived gains but also the cognitive, emotional and social factors that facilitate the growth process ${ }^{17}$. One critical factor that has been theorized to facilitate the PTG process is the confrontation with core beliefs. In this sense, a traumatic event is considered a psychologically shattering experience or an experience that challenges a person's core beliefs, forcing individuals to reexamine them ${ }^{7}$. Core beliefs are defined as a general set of beliefs that a person has about the world and their individual place within it. These beliefs also include assumptions about how one believes people will behave, how events should unfold, and one's personal ability to influence events ${ }^{18}$. After trauma, the psychological struggle triggered by the disruption of core beliefs could facilitate identification of positive changes in their worldview and a connection with others that would not have existed otherwise, resulting in the experience of $\mathrm{PTG}^{4}$. Empirical studies have supported that the reexamination of core beliefs is more closely related to growth than the perceived stressfulness of the event ${ }^{19,20}$.

To measure the degree of disruption of core beliefs after a traumatic event, the Core Beliefs Inventory (CBI) was developed. The CBI consists of nine self-report items, and responses are made on a six-point scale. Psychometric studies of the scale indicate a single-factor model and the internal reliability was good in a twostage study ( $\alpha$ time $1=.82 ; \alpha$ time $2=.87$ ) and the test-retest reliability was acceptable $(r=.69)^{20}$.

Another cognitive process that facilitates PTG is the effort to review and understand the traumatic event in order to reintegrate the shattered beliefs. Empirical and theoretical studies suggest that intrusive rumination is associated with negative reactions to trauma, whereas deliberate rumination is associated with meaning and growth ${ }^{21}$. Aiming to investigate the role of both styles of rumination in the growth process, the Event Related Rumination Inventory (ERRI) was designed 7 . The ERRI consists of 20 self-report items that are scored on a four-point scale. The original psychometric ERRI study confirmed the two-factor model, with a good internal reliability in both subscales (intrusive, $\alpha=.94$; deliberate, $\alpha=.88$ ).

Despite the increasing interest in PTG worldwide, to the best of our knowledge, there are no studies addressing this issue in the Brazilian population. The purpose of this study was to describe the steps of the process of translation and cultural adaptation to Brazilian Portuguese of the three main scales used internationally to evaluate 
the PTG phenomenon: PTGI, CBI, and ERRI. In the process of adaptation of a psychological measure to a different language and culture, content validity must be considered. The content validity is the degree to which the items of an instrument are representative of the construct being measured ${ }^{22}$. In this sense, careful translation and adaptation methods are important to ensure that the construct remains the same as that of the original instrument ${ }^{23}$. We hope that with this adaptation the scales can be psychometrically validated and used as clinical and research tools in the Brazilian context.

\section{Methods}

The translation and adaptation of the three instruments were based on the guidelines of the International Test Commission and previous studies ${ }^{24,25}$ and followed six steps: (1) translation, (2) expert committee's evaluation, (3) review by linguistic experts, (4) pretest in the target population, (5) back translation, and (6) original authors' evaluation. The study was approved by the Research Ethics Committee of the institution where it was conducted (protocol no. 247.127).

\section{Results}

\section{Translation}

Two native Portuguese-speaking authors, fluent in English, independently translated the original versions of the ERRI and CBI into Brazilian Portuguese. These versions were then merged into one initial translated version of each scale. The Brazilian version of the PTGI was based on the existing European Portuguese version ${ }^{16}$, and only minor semantic changes were made.

\section{Expert committee's evaluation}

The translated versions of the ERRI, CBI and PTGI were evaluated by an expert committee composed of four judges: two psychologists (MSc) with expertise in PTSD and two psychologists (PhD) with expertise in psychological assessment. The content validity index (CVI) ${ }^{26}$ was used to objectively measure the experts' evaluation. This index is based on a five-point Likert-type scale on which experts rate the items according to (1) clarity of language, which measures how understandable the items are to the target population; (2) practical relevance, which measures how adequate each item is to evaluate the target population; and (3) theoretical relevance, which measures how much the items are in agreement with the construct theory ${ }^{27}$. For each item, values $>0.7$ were considered satisfactory ${ }^{28}$. Items with lower scores were rephrased and resubmitted to the four judges for evaluation until the CVI reached a value of $>0.70$. Table 1 summarizes the items that were modified at this stage.

\section{Review by linguistic experts}

This phase consisted of a meeting between two linguistic experts and the authors of the study. The translated versions were compared with the original English versions not only to verify whether all items expressed the same ideas but also to ensure semantic, idiomatic and conceptual equivalence between the source-language and adapted versions. As a result of this evaluation, some expressions in the adapted versions were modified.

In the instructions for use of the CBI, the term "event" was considered problematic. In Portuguese, the most similar word to "event" is "evento", a term that generally means "party"; thus, this word was changed to a semantically similar word: "situação", which means "situation". Also, in some items of the CBI, the expression "examined" used in "I seriously examined the degree to which I believe things..." was modified considering that, in Portuguese, the most similar word to "examined" is "examinei", a verb that means to test or evaluate something. Aiming to preserve the original meaning, the word was changed to "repensei", which means thinking again.
In the ERRI, some items needed to be completely modified. Item 7 "Reminders of the event brought back thoughts about my experience" was rewritten considering that there is no similar word or expression in Portuguese to "reminders" in the context of "reminding by association". In this case, it was decided to explain the entire sentence in more detail: "Coisas do meu cotidiano relacionadas à situação me fizeram ter pensamentos sobre o que vivi”, which may be literally translated as "Things that happen in my daily life related to the situation made me think about what I have experienced". In the original ERRI, item 13 aims to investigate a deliberate effort to cope with the event: "I forced myself to think about my feelings about my experience". The experts considered that the literal translation of "I forced myself" (i.e., "eu me forcei") may have a negative connotation. The item was then changed to "Eu me esforcei para refletir sobre os meus sentimentos acerca da situação", which may be literally translated as "I made an effort to think about my feelings about the situation".

\section{Pretest in the target population}

The adapted versions of all three instruments were administered to a sample of the target population in a pilot study. The understanding of each item in the three questionnaires was evaluated using a five-point verbal numeric rating scale, ranging from "1- Incomprehensible" to " 5 - I completely understood". The sample consisted of 30 university students (10 men and 20 women), with a mean (SD) age of 24 (5.4) years. Most students were psychology undergraduates (86\%).

Satisfactory understanding was defined as a mean score $\geq 3$, a cut-off point based on previous studies ${ }^{29,30}$. None of the items of any of the three scales needed to be modified at this stage because participants rated all the items as completely understandable. All items had a mean score of four or higher.

\section{Back translation}

After all items were considered appropriate by the evaluators and understandable by the students, the adapted version of each scale was back translated by two independent, bilingual native English speakers, who were blinded to the original instrument. These two back-translated versions were merged by the authors of this study into a single back-translated version of each scale.

\section{Original authors' evaluation}

The Brazilian Portuguese adapted versions, the back-translated versions and the results of all stages were submitted to the authors of the original versions for evaluation and subsequent approval.

\section{Discussion}

This study aimed to adapt three self-report measures used to investigate PTG. In the adaptation process, the scales were evaluated and expressions were modified to preserve the content validity of the instrument in the Brazilian Portuguese version.

In the psychometric literature, the content validity of translated scales should be investigated with methodological rigor and include cross-cultural adaptation addressing both linguistic and cultural issues. Although several methods have been proposed for adaptation of existing instruments, how to conduct this process in a reliable and objective manner is still debatable. Moreover, these methodological guidelines do not cover linguistic specificities, requiring a case-bycase examination. This precaution was taken in the present study by using the CVI. This index provided quantitative data to evaluate the adequacy of the scales regarding clarity of language, practical and theoretical relevance.

A major limitation of this study was the pilot phase, since all participants were university students, mostly psychology students. As most studies investigating PTG have obtained their initial data from university students, our pilot study provides sufficient reliability 
Table 1. Results of expert committee's evaluations

\begin{tabular}{|c|c|c|c|c|c|c|c|c|}
\hline Measure & Primeira versão & $\mathrm{CL}$ & $P R$ & TR & Versão reformulada & $\mathrm{CL}$ & PR & TR \\
\hline \multicolumn{9}{|l|}{ PTGI } \\
\hline 11 & $\begin{array}{l}\text { Sou capaz de fazer coisas melhores com a } \\
\text { minha vida }\end{array}$ & 0,64 & 0,89 & 0,89 & $\begin{array}{l}\text { Agora sou capaz de fazer coisas melhores } \\
\text { com a minha vida }\end{array}$ & 0,84 & 0,99 & 0,99 \\
\hline 14 & $\begin{array}{l}\text { Apareceram oportunidades que não teriam } \\
\text { aparecido de outra forma }\end{array}$ & 0,69 & 0,74 & 0,79 & $\begin{array}{l}\text { Surgiram oportunidades que não teriam } \\
\text { surgido de outra forma }\end{array}$ & 0,84 & 0,99 & 0,99 \\
\hline 17 & $\begin{array}{l}\text { É mais provável eu mudar as coisas que } \\
\text { precisam ser mudadas }\end{array}$ & 0,69 & 0,99 & 0,99 & $\begin{array}{l}\text { Agora é mais provável que eu mude coisas } \\
\text { que precisam ser mudadas }\end{array}$ & 0,94 & 0,99 & 0,99 \\
\hline \multicolumn{9}{|l|}{ ERRI } \\
\hline Intro & $\begin{array}{l}\text { Após uma experiência como a que você } \\
\text { reportou, as pessoas - às vezes, mas não } \\
\text { sempre - se dão conta de estar pensando } \\
\text { sobre a experiência mesmo quando não } \\
\text { estão voluntariamente tentando pensar } \\
\text { sobre isso. Indique, para os itens abaixo, } \\
\text { se você teve essas experiências descritas, } \\
\text { e com qual frequência, durante as últimas } \\
\text { semanas }\end{array}$ & 0,69 & 0,99 & 0,99 & $\begin{array}{l}\text { Após uma experiência como a que você } \\
\text { reportou, as pessoas às vezes se dão conta } \\
\text { de estar pensando sobre a experiência } \\
\text { mesmo quando não estão voluntariamente } \\
\text { tentando pensar sobre isso. Indique } \\
\text { para os itens a seguir se você teve } \\
\text { essas experiências descritas e com qual } \\
\text { frequência, durante as últimas semanas }\end{array}$ & 0,94 & 0,99 & 0,99 \\
\hline 7 & $\begin{array}{l}\text { Coisas que me lembravam do evento me } \\
\text { fizeram pensar sobre a minha experiência. }\end{array}$ & 0,64 & 0,94 & 0,99 & $\begin{array}{l}\text { Coisas do meu cotidiano relacionadas } \\
\text { à situação me fizeram ter pensamentos } \\
\text { sobre o que vivi }\end{array}$ & 0,94 & 0,99 & 0,99 \\
\hline 9 & $\begin{array}{l}\text { Outras coisas me mantêm pensando sobre } \\
\text { a minha experiência }\end{array}$ & 0,69 & 0,94 & 0,99 & $\begin{array}{l}\text { Outras coisas me levaram a ficar pensando } \\
\text { sobre a minha experiência }\end{array}$ & 0,89 & 0,99 & 0,99 \\
\hline 12 & $\begin{array}{l}\text { Eu pensei se as mudanças na minha vida } \\
\text { vieram de eu ter que lidar com a minha } \\
\text { experiência }\end{array}$ & 0,44 & 0,79 & 0,99 & $\begin{array}{l}\text { Eu pensei se as mudanças na minha vida } \\
\text { vieram como consequência de eu ter } \\
\text { lidado com esta experiência }\end{array}$ & 0,84 & 0,99 & 0,99 \\
\hline 13 & $\begin{array}{l}\text { Eu me forcei para pensar sobre os meus } \\
\text { sentimentos acerca da minha experiência }\end{array}$ & 0,64 & 0,94 & 0,99 & $\begin{array}{l}\text { Eu me esforcei para refletir sobre os meus } \\
\text { sentimentos acerca da situação }\end{array}$ & 0,94 & 0,99 & 0,99 \\
\hline 20 & $\begin{array}{l}\text { Eu me forcei para enfrentar os meus } \\
\text { sentimentos em relação ao que aconteceu }\end{array}$ & 0,39 & 0,99 & 0,99 & $\begin{array}{l}\text { Eu me esforcei para enfrentar os } \\
\text { sentimentos que tive em relação à } \\
\text { situação }\end{array}$ & 0,94 & 0,99 & 0,99 \\
\hline \multicolumn{9}{|c|}{ s } \\
\hline Intro & $\begin{array}{l}\text { Alguns eventos que as pessoas vivenciam } \\
\text { são tão impactantes que "abalam seu } \\
\text { mundo" e as levam a examinar seriamente } \\
\text { suas principais convicções sobre si } \\
\text { mesmas, o mundo, as outras pessoas e } \\
\text { sobre o futuro. Por favor, reflita sobre a } \\
\text { situação sobre a qual você está reportando } \\
\text { e indique qual o grau que esta leva você a } \\
\text { repensar cada uma das convicções abaixo: }\end{array}$ & 0,69 & 0,99 & 0,99 & $\begin{array}{l}\text { Algumas situações que as pessoas } \\
\text { vivenciam são tão impactantes que } \\
\text { "abalam seu mundo" e as levam a } \\
\text { reexaminar seriamente suas principais } \\
\text { convicções sobre si mesmas, o mundo, as } \\
\text { outras pessoas e o seu futuro. Por favor, } \\
\text { reflita sobre a situação sobre a qual você } \\
\text { está relatando e indique o quanto esta } \\
\text { situação leva você a repensar cada uma } \\
\text { das convicções abaixo: }\end{array}$ & 0,84 & 0,99 & 0,99 \\
\hline
\end{tabular}

CL: clarity of language; PR: practical relevance; TR: theoretical relevance.

for use in research and to replicate these studies in Brazil. However, one must proceed with caution when conducting further studies with individuals with lower education.

Previous studies have shown that the PTGI domains may vary across cultures ${ }^{15}$. One of the main reasons is that growth is a response that depends closely on cultural meanings of negative life events, personal strength, and thriving ${ }^{31}$. In this sense, the transcultural adaptation of the three PTG-related measures is particularly important. The content validity of these measures can provide a basis for future studies indicating, in the case of psychometric data, different factors of the original instrument in the factor analysis. In this case, for instance, different findings could be attributed to the Brazilian culture rather than to differences in the item's content. Further studies are underway to determine the reliability and psychometric validity of these scales.

\section{Financial support}

Thiago Loreto Garcia da Silva and Júlia Candia Donat are recipients of scholarships from the Brazilian National Council for Scientific and Technological Development (CNPq). Christian Haag Kristensen is the recipient of a research career scholarship from CNPq. The funding source had no involvement in study design, in the collection, analysis and interpretation of data, in the writing of the report, and in the decision to submit the paper for publication.

\section{Conflict of interest}

There are no conflicts of interest concerning the publication of this article.

\section{References}

1. Breslau N. The epidemiology of trauma, PTSD, and other posttrauma disorders. Trauma Violence Abuse. 2009;10(3):198-210.

2. Creamer M, Burgess P, McFarlane AC. Post-traumatic stress disorder: findings from the Australian National Survey of Mental Health and Well-being. Psychol Med. 2001;31(7):1237-47.

3. Calhoun LG, Tedeschi RG. AUTHORS' RESPONSE: "The Foundations of Posttraumatic Growth: New Considerations”. Psychol Inq. 2004;15(1):93-102.

4. Triplett KN, Tedeschi RG, Cann A, Calhoun LG, Reeve CL. Posttraumatic growth, meaning in life, and life satisfaction in response to trauma. Psychol Trauma. 2012;4:400. 
5. Tedeschi RG, Calhoun LG. The Posttraumatic Growth Inventory: measuring the positive legacy of trauma. J Trauma Stress. 1996;9(3):455-71.

6. Zoellner T, Maercker A. Posttraumatic growth in clinical psychology - A critical review and introduction of a two component model. Clin Psychol Rev. 2006;26(5):626-53.

7. Cann A, Calhoun LG, Tedeschi RG, Triplett KN, Vishnevsky T, Lindstrom CM. Assessing posttraumatic cognitive processes: the Event Related Rumination Inventory. Anxiety Stress Coping. 2011;24(2):137-56.

8. Janoff-Bulman R. Schema-change perspectives on posttraumatic growth. In: Calhoun LG, Tedeschi RG (eds.). The handbook of posttraumatic growth: research and practice. Mahwah, NJ: Lawrence Erlbaum, 2006. p. 81-99.

9. Mols F, Vingerhoets AJ, Coebergh JWW, van de Poll-Franse LV. Wellbeing, posttraumatic growth and benefit finding in long-term breast cancer survivors. Psychol Health. 2009;24(5):583-95.

10. Bluvstein I, Moravchick L, Sheps D, Schreiber S, Bloch M. Posttraumatic growth, posttraumatic stress symptoms and mental health among coronary heart disease survivors. J Clin Psychol Med Settings. 2013;20(2):164-72.

11. Taku K, Cann A, Calhoun LG, Tedeschi RG. The factor structure of the Posttraumatic Growth Inventory: A comparison of five models using confirmatory factor analysis. J Trauma Stress. 2008;21(2):158-64.

12. Ho SMY, Law LSC, Wang GL, Shih SM, Hsu S, Hou Y. Psychometric analysis of the Chinese version of the Posttraumatic Growth Inventory with cancer patients in Hong Kong and Taiwan. Psychooncology. 2013;22(3):715-9.

13. Weiss T, Berger R. Reliability and validity of a Spanish version of the Posttraumatic Growth Inventory. Res Social Work Prac. 2006;16(2):191-9.

14. Jaarsma TA, Pool G, Sanderman R, Ranchor AV. Psychometric properties of the Dutch version of the posttraumatic growth inventory among cancer patients. Psychooncology. 2006;15(10):911-20.

15. Taku K, Kilmer RP, Cann A, Tedeschi RG, Calhoun LG. Exploring posttraumatic growth in Japanese youth. Psychol Trauma. 2012;4(4):411-9.

16. Resende C, Sendas S, Maia A. Estudo das características psicométricas do Posttraumatic Growth Inventory - PTGI - (Inventário de Crescimento Pós-Traumático) para a população portuguesa. Actas da XIII Conferência Internacional de Avaliação Psicológica: Formas e Contextos, 2008.

17. Calhoun LG, Cann A, Tedeschi RG. The posttraumatic growth model: sociocultural considerations. In: Weiss T, Berger R (eds.). Posttraumatic growth and culturally competent practice: lessons learned from around the globe. Hoboken, NJ: Wiley, 2010. p. 1-14.
18. Lindstrom CM, Cann A, Calhoun LG, Tedeschi RG. The relationship of core belief challenge, rumination, disclosure, and sociocultural elements to posttraumatic growth. Psychol Trauma. 2013;5:50.

19. Taku K, Cann A, Tedeschi RG, Calhoun LG. Core beliefs shaken by an earthquake correlate with posttraumatic growth. Psychol Trauma. 2015;7(6):563-9.

20. Cann A, Calhoun LG, Tedeschi RG, Kilmer RP, Gil-Rivas V, Vishnevsky $\mathrm{T}$, et al. The Core Beliefs Inventory: a brief measure of disruption in the assumptive world. Anxiety Stress Coping. 2010;23(1):19-34.

21. Stockton H, Hunt N, Joseph S. Cognitive processing, rumination, and posttraumatic growth. J Trauma Stress. 2011;24(1):85-92.

22. Polit DF, Beck CT. The content validity index: are you sure you know what's being reported? Critique and recommendations. Res Nurs Health. 2006;29(5):489-97.

23. Borsa JC, Damásio BF, Bandeira DR. Adaptação e validação de instrumentos psicológicos entre culturas: algumas considerações. Paidéia. 2012;22(53):423-32.

24. Beaton DE, Bombardier C, Guillemin F, Ferraz MB. Guidelines for the process of cross-cultural adaptation of self-report measures. Spine (Phila Pa 1976). 2000;25(24):3186-91.

25. International Test Commission [Internet]. International Test Commission guidelines for translating and adapting tests. 2010 [cited 2013 nov 18]. Available from: $<$ http://www.intestcom.org/upload/sitefiles/40.pdf $>$.

26. Hernández-Nieto RA. Contribuciones al análisis estadístico. Mérida Venezuela: Universidad de Los Andes/IESINFO, 2002.

27. Balbinotti MA, Benetti C, Terra PRS. Translation and validation of the Graham-Harvey survey for the Brazilian context. Int J Manage Financ. 2006;3(1):26-48

28. Clark P, Lavielle P, Martinez H. Learning from pain scales: patient perspective. J Rheumatol. 2003;30(7):1584-8.

29. Lobo BOM, Brunnet AE, Silva TLGS, Santos LMD, Gauer G, Arteche AX et al. Translation and adaptation of the Child Posttraumatic Cognitions Inventory (cPTCI) to Brazilian Portuguese. Trends Psychiatry Psychother. 2014;36(2):107-12.

30. Oliveira SES, Bandeira DR. Linguistic and cultural adaptation of the Inventory of Personality Organization (IPO) for the Brazilian culture. J Depress Anxiety. 2011;1(1):1-7.

31. Weiss T, Berger R. Posttraumatic growth and culturally competent practice: Lessons learned from around the globe. 2010. John Wiley \& Sons. 